\title{
Issues of Order in Grammar and Studies of the Albanian Language
}

\author{
Doc. Dr. Aida Kurani \\ Aleksandër Moisiu" University Durrës, Albania
}

\section{Doi:10.5901/ajis.2015.v4n3s1p157}

\begin{abstract}
Our research aims to follow the path of order development of clauses, words and sentences through the periods of time in grammar and studies of the Albanian language. Highlighting the achievements regarding our issue and identifying the problems, we aim to pave the way for new studies on the order of Albanian language. Knowing that such achievements are necessary not only because there is an Albanian linguistic tradition in the study of the order, but also to shed light on the opinions related to the order in Albanian, as well as some problems concerning it. To see how such units are dealt with in our linguistics, we considered the known grammars of the Albanian language in a chronological order, starting from the earliest days until today. The focus of consultation for a series of issues closely related to our work has been also the research made by various local or foreign authors.
\end{abstract}

Keywords: order of clauses, order of sentences, period, syntax.

\section{Introduction}

The order of words and parts is one of the most important tools in forming a speech. It is conditioned by different factors and carries out several functions within a sentence. In the Albanian language, the order of words is relatively free, the parts of the speech can be put in different places without changing their syntax function. The order of periodic sentences is important for the structure and the value of the period. Ranking periods have a fixed and unchanged order due to semantic reasons. Any changes in them would lead to a change in the previous semantic relations. For instance, in the following speech "Kishte nxehtë dhe i pihej ujë", we cannot reverse its order, because we would ruin the meaning. In any other case, this order cannot change for structural reasons, i.e, in the second sentence, there are words that mention or refer to a word which is in the first sentence and a reversed order would be meaningless, for instance: "Urbani u ndal në qendër të qytetit dhe prej tij zbritën pasagjerët". Here, the phrase "prej tij" describes the word "urban", therefore we cannot have any other order. The change of order, in this case, would change the logical flow of events.

The order of ranking sentences cannot be changed, even when we have a passage of time, for instance: "Ajo hodhi dru në sobë dhe u ul pranë meje."

In the Albanian grammar, the order of composite periodical sentences with sub ranking words and the order of parts in these sentences has been dealt with very little. Spiro Flogi says that at least, up until the time that he wrote, the issue of the order of words in a sentence and the periodical sentences with sub ranked periodical sentences, has not been dealt with at all by Albanian syntaxologists or it has been dealt with to a very small extent. Floqi (1969: 125)

In his syntax, A. Xhuvani (1922:22), divides speeches into speeches with a direct order and speeches with an indirect order. Thus, the author divides sentences with an ordinary order: subject+predicate + direct object+adjunct and sentences with an unnatural order and vice versa.

Ilia Dilo Sheperi (1927) makes a more in depth analysis of the topic of order. Like A. Xhuvani, he divides sentences with an ordinary order and those with a non ordinary order and makes important remarks on the order of sub ranking sentences.

In his school text, Justin Rrota (1942), like prof. A Xhuvani, talks about the order in a simple speech and divides the direct order from the indirect order, which according to him, are defined by the position of the main parts subjectpredicate. In other words, we have a direct order, when the subject is in front of the direct object and when the direct object comes after the subject, then this is an indirect order of words in a speech.

The author also talks about the order of the second parts of the speech, also mentioning the order of short forms of the object or personal pronouns, which, like he points out, are located after the verb, if they are in the first person singular or plural, but they can even go before the verb without ruining the semantic of the sentence.

As far as the order of sub ranking sentences are concerned, J. Rrota says that in the Albanian language, the 
topical is free and sub ranking sentences can come out in three positions as opposed to the main sentence:

1) After the main sentence and this is the most ordinary order; for example: Mate vrapin, sa të kesh hapin.

2) In front of the main speech; for example: Kush ec kahdalë, shkon shëndosh e larg.

3) Sub ranking sentences can enter between the parts of the main sentence; for instance: Mali, si t'i thuesh, të përgjegjë. ( Rrota, 1942: 57).

In his syntax, S. Prifti (1971), after stressing the importance of the order as a very important instrument to express syntax relationships in a speech, makes several theoretical generalizations, seeing order from a functional point of view. Although, like Prifti notes, there hasn't been any special studies in relation to the order of words in the Albanian language, the author has also tried to set out sever rules for the order of words and sub ranking sentences.

In his text, M. Domi (Domi, 1955, 1969, 1971), talks about the order of words and parts in a sentence. He notes that this order can be direct and indirect.

The first order is an ordinary order: subject- predicate - direct object-adjunct which features indicative sentences interrogative sentences, which express the subject with an interrogative pronoun.

According to Domi, if in the interrogative sentences, the subject is not an interrogative pronoun, it goes before the predicate, while the direct object can go before the predicate or subject or even at the start of a sentence. According to him, adjuncts can go in different places, depending on what we want to stress.

As far as the in depth analysis is concerned, we can distinguish S. Floqi's studies. In his studies, Floqi (1969, 1976) says that the study of the order of words in the Albanian language is of a great importance. On his article "About a topic of the order of words in today's language" (Floqi, 1969:140), he rejects the thesis of the foreign researcher Klaus Hebler for the borrowed character of the order of time and subjunctive sentences in the Albanian language and he also rejects arguments that protect this thesis. Making a comparison with the order of words in Greek. Floqi rejects the arguments about the borrowing of the order of words in subjunctive sentences from Greek.

Although in general, Floqi is focused on the order of parts in time and subjunctive sentences, he also lays out a number of theoretical issues which relate to the order of parts in sub ranking sentences in general and namely:

1) When we look into the order of words in sub ranking sentences, we must not see the position of the predicate as opposed to the subjunctive tool, but the position of the main parts and secondary parts, starting with the most simple types subjective-predicate up to the most complicated types. Thus, we must look into all the possible combinations of the parts in the sub ranking sentence.

2) The order of parts in a sub ranking sentence is conditioned by three main reasons: a) by mere structural reasons (in definitive sentence); b) by the narrative weight of a part or a group of parts during the actual analysis of the sentence; $c$ ) by new nuances that relate to the meaning, adding to the basic meaning of a particular type of period in a sub ranking sentence.

3) In subjunctive sentences, the position of the predicate and the subject doesn't directly depend on the subjunctive tool. However, one type of conjunction can have an indirect effect on the order of words through their semantic, such as consequential conjunctions originating from adverbs, while explanative conjunctions, which are empty on the semantic point of view, do not have this effect.

In the same line with S. Floqi is also M. Totoni (1997), expanding his studies on order. In his article "The order of parts in sub ranking sentences and the problem of the impact of Greek" (Totoni, 1997:642), the author deals with not only problems of the order of parts in definitive and time sentences, but also in other sub ranking sentences. For Totoni, the principles and rules that are followed by Floqi, are right in essence and their application would offer important results in both the synchronic aspect and also the diachronic one, but of course, according to him, they can be elaborated even more.

Like Floqi, Totoni too rejects Hebler's thesis. According to Totoni, Floqi rightfully points out that by putting the predicate before the conjunctive tool in time and definitive sentences, goes well for fairy tale genre. He argues that this order is conditioned by the current fragmentation and is determined by the stylistic features of this genre, where action and short sentences dominate. But in the literary language, it's not the same thing, which by expressing a deeper content, it has refined more complicated forms of the order of words.

We also support Flogi's and Totoni's opinion according to whom, explainable regularities act within the Albanian language in the order of parts in a sub ranking sentence, conditioned by morphologic, syntax and stylistic features. During its development, the Albanian language has and still uses its internal tools and has not been affected from abroad. The main function 0 fthe order of the words in the Albanian language, at least since Buzuku, is the actualizing-stylistic function; the order of parts in a speech is made according to the weight that they have in the saying that contains a phrase. The order of parts in the sub ranking, be it in colloquial language, be it in the fairy tale language, be it in different 
styles of the literary language, is regulated to adapt to this function.

Hebler would be right if he pointed out a diversion from this rule, a diversion which would be similar to all specific rules of the order of parts in Greek. But neither the one, nor the other is true. The similarity in the order of words in Albanian with Greek cannot be considered as an impact, given that this order in the Albanian language is later documented in the Greek language. Something cannot be called a borrowing of a certain order or even a specimen which is in compliance with today's rules of the Albanian language.

The novelty that Totoni brings is that he justifies the embedded order of the predicate with the distribution that determines the different function of several words such as conjunctives or adverbs (for instance, si, sa, tek, posa, nga, etc). This embedded order of the predicate after these words has been forced to avoid double meanings that can be created in some cases. (Totoni, 1997: 643).

R. Përnaska $(1979,1987)$ points out that the order of parts is closely linked to the functional perspective, with an actual fragmentation. He also talks about a direct order, when the order is subject+ verb predicate or noun predicate, predicate+ direct object; predicate +adjunct and an indirect order, when we have, for instance, verb or noun predicate + subject. He too stresses that the main function of the order of parts in the Albanian language has to do with the current fragmentation of the saying. The logical accentuation plays an important role in the current fragmentation in the organization of functional perspective, but such thing, according to him, deserves special attention.

For this article, R. Përnaska also defines the language tools (lexical and grammar), which serve to express the meaning of the saying. Among them, besides the question which serves to find the phony, the order of parts in a speech, tone, nouns (according to the type, general or impersonal, concrete or abstract), adjectives, pronouns (të gjithë, të tërë, diçka, etc), parts (enforcing-complementary or separate, definitive-affirmative, negative), some specialized syntax constructions, the forms of a noun and the short forms of personal pronouns, etc.

Th. Rushi $(1983,1988)$ has paid special attention to the order in his works. In the article "About the order of parts in a narrative sentence", the author analyzes issues of the parts in a narrative sentence, talking about factors that condition the order of parts in a simple narrative sentence with a subject, predicate and direct object. (Rushi, 1983:46).

The author admits that the order of parts in a narrative sentence in the Albanian language is free, but this must be understood in a relative manner. In rare cases, this order can also be embedded: subject at the beginning, then the predicate and then the direct object. As far as the latter is concerned, Th. Rushi mentions the case of sentences in which the subject and object are expressed in the same form, when other grammatical, lexical and contextual indicators are lacking, to help define their function. (Rushi 1983: 29). In this case, it's the order of parts that this function determines, which decides which one is the subject and which one is the direct object. Therefore, it points out one of the cases of syntax function of the order of words, where other grammatical indicators which carry out this function, are lacking.

Another important function in the Albanian language is the one that relates to the current fragmentation of the Albanian language. According to him, the order of order in this case is that the part or the parts that make up the topic, are put at the beginning of the speech; while on the other hand, the part or parts that make up the phone, are put at the end. Th. Rushi sees this function of the order of the words as closely tied to the tone, especially with the logical accentuation. Rushi also lays out the cases of the order of parts in a systematic way.

In the Academy Grammar (Grammar, 1996), the study of the order has been analyzed in deep. The following is said about the order of parts in a sentence in this wordk: "The place of the parts of a sentence is determined by different factors, mainly actual fragmentation, stylistic reasons and rarely from their syntax function." (Grammar, 1996: 415) Given that actual fragmentation also determines the order of parts in a sentence. We can do the same by relying on the order of parts to determine the topic and its phony, in some cases even helped by the logical accentuation, which always falls on the phony and also indicated by indicators such as: enforcement parts, separate or negative, the use or non use of the short form of the predicate, the use of personal pronouns of the first and second person, the form and the meaning of nouns, etc., furthermore, the terminology that relates to current fragmentation will be used: topic, phony, direct order (subject+ predicate, predicate + object, predicate+ adjunct), reversed order (predicate + subject, object + predicate etc.), neutral order (topic + phony) or the emphatic affective order (phony+ topic). (Grammar, 1996: 414).

We also believe that the order of parts in a sentence is seen and is taken into account with the aim of determining the topic and the phony, which are known and unknown, the novelty of the saying. In this aspect, when we look at the position of the flowing sub ranking sentence in relation to the main or directive sentence, we will take into account the above mentioned lexical or grammatical tools, which can help us in order to determine the type of the order of the sub ranking sentence in the period. 


\section{Conclusions}

In conclusion, we can say that the grammars of the Albanian language have spoken about order, although not to a great extent. What joins these analyses relates to the main functions of the order of words and parts in a sentence, the relatively free order of words and parts in the Albanian language, the link of order with the current fragmentation and the emotional power of a particular construction, the impact of the type of sentence based on the narration and the use or not of the short form object of the personal pronoun in particular constructions depending on the order.

It's fair to make a distinction between the direct order (subject + predicate, predicate+ object, predicate + adjunctive) and a reversed order (predicate + subject, object + predicate, etc) on one hand and neutral order (topic + phony) or emphatic affective order ( phony + topic). In both terms, we are in the functional domain of the analysis of the sentence. Thus, we are dealing with the order of the functional parts of the sentence: subject, predicate, object and so on. In the second case, we are in the domain of actual fragmentation of the sentence into something known and something unknown, thus we have to do with communication.

It has been widely accepted that in the Albanian language, order is relatively free, thus the parts can assume different positions without changing their syntax function.

The relatively free order of parts in a sentence seems to be a general feature of the Albanian language, which has a developed inflection, therefore the order doesn't play any special role in the syntax or meaning of the sentence or the period in general. In relation to the topical of words in a sentence, E. Cabej too says that the richer a language is in the inflection system, the freer the topical of words is in a sentence. And vice versa, the poorer the inflection is, the stricter the topical is. For instance, we have the Latin expression: Civis diligit patriam (The citizen loves his fatherland). According to the author, here it's clear that civis is subjunctive and patriam relates to the object.

Even if this topical is reversed: Patriam civis diligit, the meaning doesn't change. (Çabej, 2008: 223).

He bases this on the Greek linguistic, F. Kieckero, who also speaks of the order of words in the Albanian language and the Austrian researcher, Wolfgang Dresler, who points out that the Albanian language often has a tendency to put the verb before the subject. (Çabej, 1976: 125).

\section{References}

Akademia e Shkencave, Gramatika e gjuhës shqipe II, Sintaksa, Tiranë, 1997.

Cipo, K. (1951). Sintaksa (Tekst për Institutin Pedagogjik), Tiranë.

Çabej, E. (2008). Hyrje në Indoeuropianistikë, Leksionet e Prishtinës, Botimet Çabej, Tiranë, 2008.

Domi, M. (1971). Sintaksa e gjuhës shqipe, Prishtinë.

Floqi, S. (1969). "Mbi disa çështje të rendit të fjalëve në shqipen e sotme", Studime filologjike, Tiranë, 1969.

Floqi, S. (1976). Disa vrojtime për rendin e fjalive në periudhë, Studime filologjike, Nr. 3.

Përnaska, R. (1979). Një rast i veçantë i rendit të gjymtyrëve në fjalinë e përbërë në gjuhën shqipe, Studime filologjike. Tiranë.

Prifti, S. (1971). Sintaksa e Gjuhës Shqipe, Prishtinë.

Rrota, J. (1942). Syntaksa e gjuhës shqipe (ose Sintaksi i shqipes 1942) për klasën II, III, IV të shkollave të mesme, Shkodër, shtypshkronja A. Gj. Fishta, Shkodër.

Sheperi, I. D. (1927). Gramatika dhe Sintaksa e gjuhës shqipe, Vlorë.

Totoni, M. (1995). Struktura sintaksore e gjuhës letrare shqipe dhe probleme të normës së saj, Gjuha jonë, nr. 1-4.

Totoni, M. (1997). Rendi i gjymtyrëve në fjalitë e nënrenditura dhe problemi i ndikimit të greqishtes, Kumtesë e mbajtur në seminarin për gjuhën dhe kulturën shqiptare, Tiranë, gusht-shtator .

Xhuvani, A. (1922). Njohunit’e para të sintaksës shqipe, pjes` e parë për klasët e nalta të fillores, Vlorë. 